\title{
A method for measuring activated factor VIII in plasma
}

Citation for published version (APA):

Kessels, H., Beguin, S., Wagenvoord, R., \& Hemker, H. C. (1991). A method for measuring activated factor VIII in plasma. Thrombosis and Haemostasis, 66(4), 430-434. https://doi.org/10.1055/s-00381646433

Document status and date:

Published: 01/01/1991

DOI:

10.1055/s-0038-1646433

Document Version:

Publisher's PDF, also known as Version of record

\section{Please check the document version of this publication:}

- A submitted manuscript is the version of the article upon submission and before peer-review. There can be important differences between the submitted version and the official published version of record.

People interested in the research are advised to contact the author for the final version of the publication, or visit the DOI to the publisher's website.

- The final author version and the galley proof are versions of the publication after peer review.

- The final published version features the final layout of the paper including the volume, issue and page numbers.

Link to publication

\footnotetext{
General rights rights.

- You may freely distribute the URL identifying the publication in the public portal. please follow below link for the End User Agreement:

www.umlib.nl/taverne-license

Take down policy

If you believe that this document breaches copyright please contact us at:

repository@maastrichtuniversity.nl

providing details and we will investigate your claim.
}

Copyright and moral rights for the publications made accessible in the public portal are retained by the authors and/or other copyright owners and it is a condition of accessing publications that users recognise and abide by the legal requirements associated with these

- Users may download and print one copy of any publication from the public portal for the purpose of private study or research.

- You may not further distribute the material or use it for any profit-making activity or commercial gain

If the publication is distributed under the terms of Article $25 \mathrm{fa}$ of the Dutch Copyright Act, indicated by the "Taverne" license above, 


\title{
A Method for Measuring Activated Factor VIII in Plasma
}

\author{
H. Kessels, S. Béguin, R. Wagenvoord, and H.C. Hemker \\ From the Department of Biochemistry, University of Limburg, Maastricht, The Netherlands
}

\section{Summary}

A method is described which enables a quantitative measurement of the concentration of activated factor VIII (VIIIa) in plasma. Based on the ability of factor VIIIa to accelerate the activation of factor $\mathrm{X}$ by factor IXa, phospholipid and calcium ions, the course of factor $\mathrm{X}$ activation in time is measured using a chromogenic substrate. Free factor $\mathrm{Xa}$ is able to activate nonactivated factor VIII present in a plasma sample, which increases the factor $\mathrm{X}$ activation velocity, and thus disturbs the measurement of factor VIIIa. Furthermore, factor Xa was found to be inactivated by serine protease inhibitors from the plasma sample. By adding surplus chromogenic substrate these reactions of factor $\mathrm{Xa}$ are inhibited and at the same time the rate of substrate conversion is a measure of the amount of factor $\mathrm{Xa}$ present. Factor $\mathrm{X}$ activation and amidolysis of chromogenic substrate then take place simultaneously. It is shown that under proper conditions the factor $\mathrm{X}$ activation velocity is linearly proportional to the factor VIIIa concentration. This causes the optical density to increase as a parabolic function of time. The concentration of factor VIIIa can be obtained from the quadratic coefficient of the equation describing the parabola. The method is specific for factor VIIla in that the extrinsic factor $\mathrm{X}$ activator is shown to have no influence on the measurement of factor VIIIa in thromboplastin activated plasma. We conclude that a sensitive and reliable method for assessing factor VIIIa concentrations in plasma has been developed on the basis of simultaneous inhibition and measurement of factor $\mathrm{Xa}$ by a high concentration of chromogenic substrate.

\section{Introduction}

Clot formation in plasma is initiated by the serial enzymatic activation of clotting factors, which results in the appearance of small traces of thrombin (1). The explosive nature of the coagulation process is a consequence of the positive feedback reactions that these thrombin traces exert on the cofactors $\mathrm{V}$ (2-4) and VIII (4-9), and on platelets, in case of platelet rich plasma (10). Activated factors V and VIII boost the performance of factors $\mathrm{Xa}$ and IXa, whereas activated platelets provide, among other things, the negatively charged surface necessary for most coagulation reactions (11).

As the line separating thrombosis and bleeding seems to be a thin one, the importance of control mechanisms that steer the hemostatic process is obvious. In spite of the enormous progress that has been made by studies in systems with purified clotting factors, the fine tuning of hemostasis in vivo still remains a largely unsolved riddle. The initial traces of thrombin and the feedback reactions they provoke, are likely to play a crucial role in the overall process of hemostasis. Therefore, we set out to develop a method to assess directly one of those feedback reactions in plasma, viz. the activation of factor VIII.

Correspondence to: Dr. S. Béguin, Dept. of Biochemistry, University of Limburg, P.O. Box 616, 6200 MD Maastricht, The Netherlands
Traditionally, factor VIII concentrations, and also factor VIII activation in plasma were measured using coagulation assays, involving VIII deficient plasma (12-17). The occurrence of various feedback reactions made it impossible to relate, in a quantitatively reliable way, obtained values to amounts of factor VIII activated. The advent of a chromogenic substrate for factor Xa made a more direct way of determining functional factor VIIIa conceivable. The property of activated factor VIII, to accelerate the activation of factor $\mathrm{X}$ by factor $\mathrm{IXa}$, phospholipid and calcium ions, by several orders of magnitude, was molded into a sensitive assay procedure for VIIIa $(16,17)$. However, feedback reactions of factor Xa on factor VIII (18-21) and factor X (22), and the inactivation of factor $\mathrm{Xa}$ by the antithrombin III and $\alpha 1$-antitrypsin present in plasma, can seriously hamper the feasibility of using the same type of assay for the measurement of factor VIIIa in plasma. On the basis of a method by Pieters et al. (4) we developed a scheme for measuring factor VIIIa in plasma, that circumvents these difficulties.

\section{Materials and Methods}

Materials. Factor Xa chromogenic substrate $\left(\mathrm{CH}_{3} \mathrm{OCO}-\mathrm{D}-\mathrm{CHG}-\mathrm{Gly}-\right.$ Arg-pNA-AcOH) and thrombin inhibitor $\alpha$-NAPAP (N- $\alpha$-(2-Naphtylsulfonyl-glycyl)-D,L-Amidinophenyl-alanine-piperidine $\mathrm{HCl}$ ) were obtained from Pentapharm (Basel, Switzerland), $\alpha$-NAPAP in a concentration of $1 \mu \mathrm{M}$ inhibits thrombin mediated amidolysis of factor Xa chromogenic substrate for $99.5 \%$, whereas factor $\mathrm{Xa}$ is inhibited no more than $1 \%$, where thrombin concentration is $20 \mathrm{nM}$ and factor $\mathrm{Xa}$ concentration $0.75 \mathrm{nM}$ (23). Buffer used was $50 \mathrm{mM}$ Tris, $175 \mathrm{mM} \mathrm{NaCl}, 0.5 \mathrm{~g} / \mathrm{l}$ ovalbumin, pH 7.9. All chemicals were to the highest grade commercially available.

Proteins. Bovine factors X, Xa, IXa and IIa were purified as previously described (24-27).

Phospholipid. Phospholipid vesicles (PL) used were 80 mole-\% egg phosphatidyl choline and 20 mole- $\%$ brain phosphatidyl serine (Sigma). They were prepared as described by Rosing et al. (28).

Preparation of plasma and euglobulins. Plasma was prepared (29) from blood from 12 healthy male donors, 9 volumes collected on 1 volume of trisodium citrate $(0.13 \mathrm{M})$. Plasma was defibrinated by mixing an aliquot of plasma with $1 / 50$ volume of reptilase reagent (Boehringer Mannheim), letting a clot form for $5 \mathrm{~min}$ at $37^{\circ} \mathrm{C}$ and keeping the clotted plasma at $0^{\circ} \mathrm{C}$ for $10 \mathrm{~min}$. The fibrin formed was discarded by winding on a small plastic spatula. Euglobulins were prepared from plasma by precipitation at low ionic strength, pH 5.2 (plasma diluted 1 in 20 in a 0.016 vol- $\%$ acetic acid solution), on ice for $30 \mathrm{~min}$. After centrifugation (10 min, $\left.4,000 \mathrm{rpm}, 4^{\circ} \mathrm{C}\right)$, they were resuspended in 5 volumes $\mathrm{NaCl}$-aq $(9 \mathrm{~g} / \mathrm{l})$ and 1 volume trisodium citrate $(0.13 \mathrm{M})$, so as to contain a concentration of factor VIII that was not lower than $75 \% .10 \mathrm{nM}$ factor Xa remains stable in this solution for over $1 \mathrm{~h}$, in the presence of $0.1 \mathrm{U} / \mathrm{ml}$ heparin. Hemophilia A plasma was obtained from a single donor and it contained less than $1 \%$ factor VIII activity.

Human brain thromboplastin was prepared as described by Owren and Aas (30). It was subsequently centrifuged at $1,000 \mathrm{rpm}$ for $5 \mathrm{~min}$ and stored in $50 \mu \mathrm{l}$ aliquots at $-80^{\circ} \mathrm{C}$. It was thawed and diluted 1 in 18 with buffer containing $167 \mathrm{mM} \mathrm{CaCl}_{2}$, then incubated at $37^{\circ} \mathrm{C}$ for $1 \mathrm{~h}$, and kept at room temperature.

Experimental conditions. Final concentrations of the reactants used were: factor IXa: $100 \mathrm{nM}$, PL: $20 \mu \mathrm{M}, \mathrm{Ca}^{2+}: 5 \mathrm{mM}$ and factor X: $330 \mathrm{nM}$. These are described by Wagenvoord (23) to be optimal for 
factor $\mathrm{X}$ activation in a bovine system with human factor VIIIa. The same holds for $\mathrm{pH}(7.9)$ and PS : PC ratio of the phospholipid vesicles (20/80 mole/mole). All experiments were performed at $37^{\circ} \mathrm{C}$.

Factor Xa assay, $300 \mu \mathrm{l}$ from a factor $\mathrm{X}$ activation mixture was subsampled in $372 \mu \mathrm{l}$ buffer containing $20 \mathrm{mM}$ EDTA. This can be shown to stop factor X activation instantaneously. After addition of $28 \mu \mathrm{l}$ of the chromogenic substrate for factor Xa, to a final concentration of $80 \mu \mathrm{M}$,

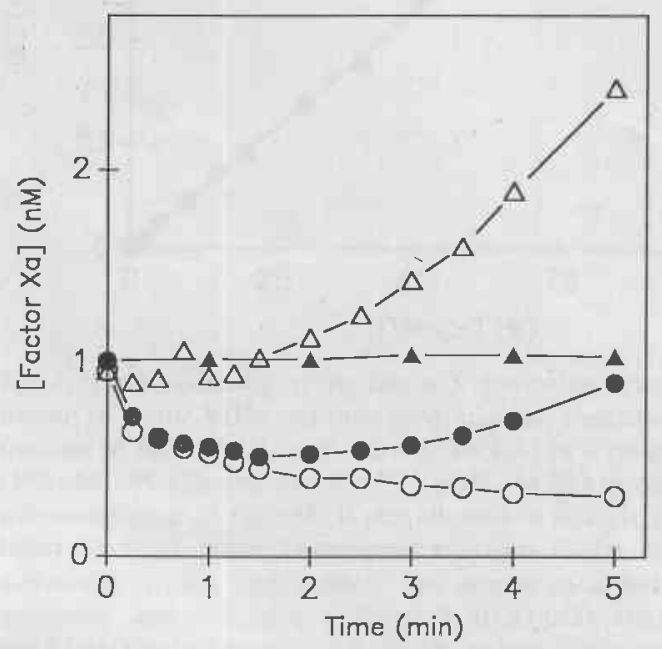

Fig. 1 Influence of factor $\mathrm{Xa}$ on factor $\mathrm{X}$ activation. To a mixture of factor IXa $(100 \mathrm{nM}), \quad \mathrm{PL} \quad(20 \mu \mathrm{M}), \quad \mathrm{Ca}^{2+}(5 \mathrm{mM})$ and $\alpha$-NAPAP $(2.33 \mu \mathrm{M})$, factor $\mathrm{X}$ was added to a final concentration of $0.33 \mu \mathrm{M}$. At $1 \mathrm{~min}$, plasma (closed circles), hemophilia A plasma (open circles), euglobulin fraction (open triangles) or buffer (closed triangles) were diluted 1 in 30 in this mixture. One min later, factor Xa was added to a final concentration of $1 \mathrm{nM}$. At intervals $300 \mu \mathrm{l}$ were taken from this mixture for assay of factor $\mathrm{Xa}$, as described in the materials and methods section

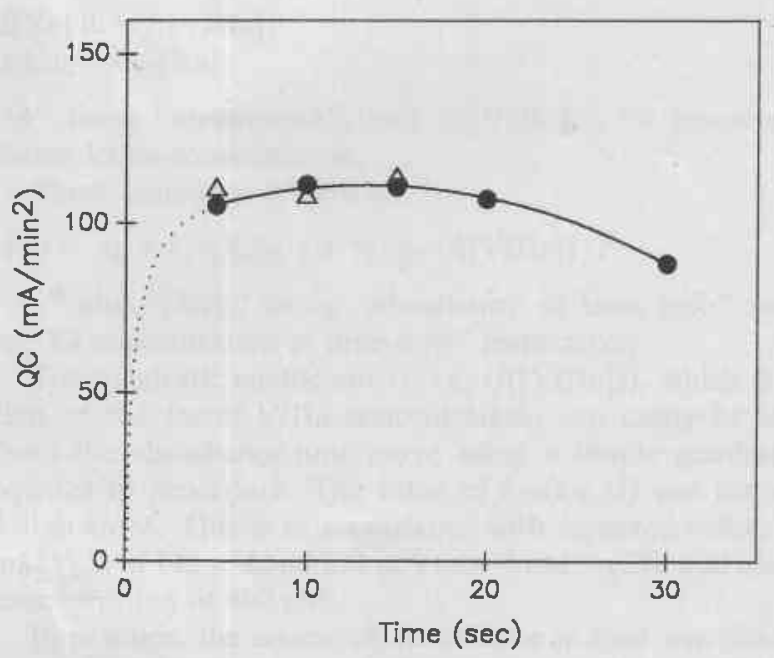

Fig. 2 Stabilization of factor VIIIa. Plasma was diluted 100 fold in a cuvette containing IXa $(100 \mathrm{nM}), \mathrm{PL}(20 \mu \mathrm{M})$ and $\mathrm{Ca}^{2+}(5 \mathrm{mM})$. At $30 \mathrm{~s}$ thrombin was added to concentrations of $100 \mathrm{nM}$ (closed circles, mean of three experiments) or $200 \mathrm{nM}$ (open triangles). At various times hereafter, chromogenic substrate for factor Xa $(400 \mu \mathrm{M})$ and $\alpha$-NAPAP $(1 \mu \mathrm{M})$ were added. The course of absorbance in time was measured upon addition of factor $\mathrm{X}(0.33 \mu \mathrm{M}), 10 \mathrm{~s}$ later. On the vertical axis are the values of the quadratic coefficient (QC) of the equation describing the absorbance time curves $\left(1 / 2 \cdot k_{2} \cdot f\right.$ ([VIIIa]), see eq. III). They were obtained using a quadratic least squares fit procedure. As we were not able to determine the course of factor VIII activation during the first $5 \mathrm{~s}$ after thrombin addition, the curve shown is putative and plotted as a dotted line absorbance was read kinetically for 2 min. The factor Xa concentration could be inferred from the initial linear increase in absorbance, using a linear least squares fit procedure. All mixtures that were assayed for factor $\mathrm{Xa}$, contained $2.33 \mu \mathrm{M} \alpha$-NAPAP, resulting in a final concentration of $1 \mu \mathrm{M}$, thereby blocking thrombin activity towards the chromogenic substrate for factor Xa for more than $99 \%$.

Measurement of absorbance. All photometry was carried out at $405 \mathrm{~nm}$ in a sensitive dual wavelength photometer.

\section{Results}

Since factor VIIIa is not an enzyme, its functional concentration cannot be measured directly by way of a chromogenic substrate. Instead, the ability of factor VIIIa to enhance factor X activation by factor $\mathrm{IXa}$, phospholipid, and $\mathrm{Ca}^{2+}$, must be exploited. The concentration of factor $\mathrm{Xa}$ can be determined chromogenically, which permits an estimation of the factor VIIIa level.

\section{Activation of Factor VIII by Factor $\mathrm{Xa}$}

It is long known that factor Xa is able to activate factor VIII, be it less effectively than thrombin. Since in plasma, the medium for which we intended to develop the factor VIIIa assay, both activated and non-activated factor VIII may be present, this feature of factor $\mathrm{Xa}$ is a potential hazard to the reliability of any method.

The effect of factor $\mathrm{Xa}$ on the time course of factor $\mathrm{X}$ activation was investigated by adding a small quantity of factor $\mathrm{Xa}$ to a mixture containing factors IXa and $\mathrm{X}$, PS:PC vesicles, $\mathrm{Ca}^{2+}$ and non activated plasma. Thrombin mediated activation of factor VIII was prevented by the presence of the thrombin inhibitor $\alpha$-NAPAP. In case of factor Xa activation of factor VIII, this will result in the formation of complete tenase, the complex of factors IXa and VIIIa on a phospholipid surface, which leads to an increase of the factor Xa concentration. When factor Xa would not act on factor VIII, factor Xa concentration would remain unaltered.

Rather surprisingly, Fig. 1 shows an initial drop of the factor Xa concentration which is followed by an increase. When the experiment was repeated with hemophilia A plasma, and with the euglobulin fraction of normal plasma (no serine protease inhibitors), either the downward or the upward bend of the curve was found to disappear. Using buffer instead of plasma causes the factor Xa concentration to remain constant.

Thus it seems likely that factor $\mathrm{Xa}$ indirectly causes factor $\mathrm{X}$ activation by activating factor VIII, but also that factor $\mathrm{Xa}$ is subject to inactivation by inhibitors (ATIII, $\alpha 1$ antitrypsin) present in the diluted plasma. When the experiments were repeated with a high concentration of hirudin $(1.25 \mu \mathrm{M})$ instead of $\alpha$-NAPAP, a similar course of $\mathrm{X}$ activation was obtained (results not shown).

Both effects, factor Xa mediated activation of factor VIII and factor $\mathrm{Xa}$ inactivation directly affect the signal used for the determination of factor VIIIa. Because the measurement is based on the ability of factor Xa to split chromogenic substrate, adding a factor $\mathrm{Xa}$ inhibitor will be effective to inhibit these undesired reactions, as well as the factor $\mathrm{Xa}$ measurement itself.

\section{Inhibition of Factor Xa by Chromogenic Substrate}

The only "inhibitor" that can dampen the side reactions without influencing signal generation is the chromogenic substrate for factor $\mathrm{Xa}$, at a concentration sufficiently above $K_{\mathrm{m}}$. This would prevent all reactions of factor $\mathrm{Xa}$ but amidolysis of chromogenic substrate. It means that factor $\mathrm{X}$ activation by the 


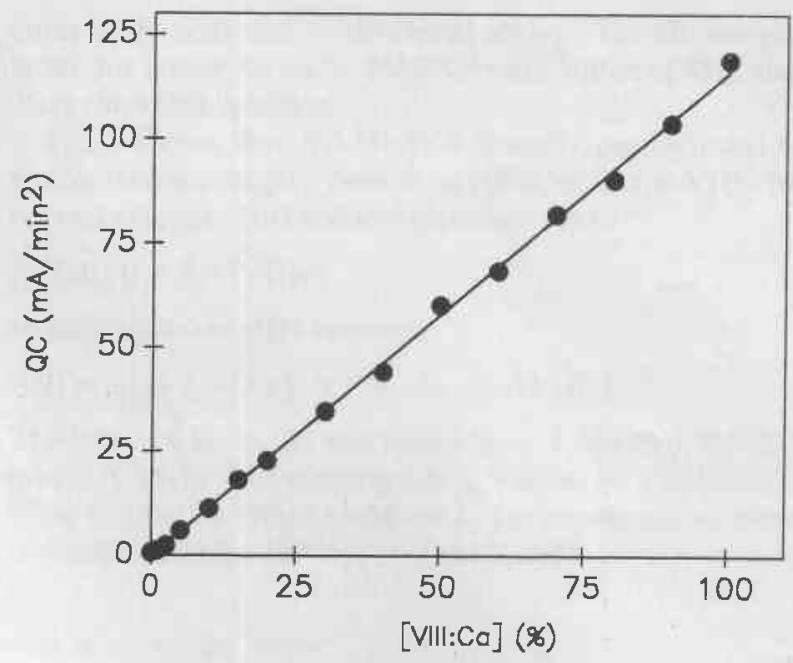

Fig. 3 Proportionality of the factor $\mathrm{X}$ activation velocity to the concentration of factor VIIIa. At time zero, plasma, containing various concentrations of factor VIII, was diluted 100 fold in a cuvette containing IXa $(100 \mathrm{nM}), \mathrm{PL}(20 \mu \mathrm{M})$ and $\mathrm{Ca}^{2+}(5 \mathrm{mM})$. At $30 \mathrm{~s}$ thrombin was added, to a concentration of $100 \mathrm{nM}$. It was allowed to activate factor VIII for $15 \mathrm{~s}$ (until $t=45 \mathrm{~s}$ ), when chromogenic substrate for factor Xa $(400 \mu \mathrm{M})$ and $a$-NAPAP $(1 \mu \mathrm{M})$ were added. The course of absorbance in time was measured upon addition of factor $\mathrm{X}(0.33 \mu \mathrm{M})$ after another $10 \mathrm{~s}$ (at $t=55 \mathrm{~s}$ ). On the vertical axis are the values of the quadratic cocfficient (QC) of the equation describing the absorbance time curves $\left(1 / 2 \cdot k_{2} \cdot f\right.$ ([VIIIa]), see eq. III). They were obtained using a quadratic least squares fit procedure. The concentration of VIII in the plasma was varied by mixing pooled normal plasma with hemophilia A plasma

tenase complex and chromogenic substrate conversion are two concurrent processes.

The following equations describe these simultaneous reactions in the mixture:

$\mathrm{d}[\mathrm{Xa}] / \mathrm{d} t=f([\mathrm{VII} \mathrm{a}])$

$\mathrm{d} A / \mathrm{d} t=k_{2} \cdot[\mathrm{Xa}]$

" $A$ " being "absorbance", and " $f([$ VIIIa] $]$ ", "a function of the factor VIIIa concentration".

These equations resolve in:

$A(t)=A_{0}+k_{2} \cdot[\mathrm{Xa}]_{0} \cdot t+1 / 2 \cdot k_{2} \cdot f([\mathrm{VIIIa}]) \cdot t^{2}$

" $A_{0}$ " and "[Xa $]_{0}$ " being "absorbance at time zero" and "factor Xa concentration at time zero" respectively.

The quadratic coefficient $\left(1 / 2 \cdot k_{2} \cdot f([\right.$ VIIIa $\left.])\right)$, which is a function of the factor VIIIa concentration, can easily be obtained from the absorbance-time curve using a simple quadratic least squares fit procedure. The value of $k_{2}$ (eq. II) was found to be $170 \mathrm{~mA} / \mathrm{nM}$. This is in accordance with reported values for $K_{\mathrm{m}}$ and $V_{\max }$ of $142 \mu \mathrm{M}$ and $230 \mathrm{~mA} \mathrm{~min}^{-1} \mathrm{nM}^{-1}$ (23), and a substrate concentration of $400 \mu \mathrm{M}$.

In practice, the course of absorbance in time was determined using the following general scheme: A sample from the mixture being assayed was diluted in a cuvette containing IXa $(100 \mathrm{nM})$, PI $(20 \mu \mathrm{M}), \mathrm{Ca}^{2+}(5 \mathrm{mM})$ and $\alpha$-NAPAP $(1 \mu \mathrm{M})$. After $10 \mathrm{~s}$, chromogenic substrate for factor Xa was added, to a concentration of $400 \mu \mathrm{M}$. Factor $\mathrm{X}$ activation was started after another $10 \mathrm{~s}$ by addition of factor $\mathrm{X}$ to a concentration of $0.33 \mu \mathrm{M}$ (concentrations were obtained after all additions had been made). The course of the absorbance in time was then measured at $405 \mathrm{~nm}$.

The influence of factor $\mathrm{Xa}$ in this system was again investigated by adding a small quantity $(1 \mathrm{nM})$ of factor $\mathrm{Xa}$ to the factor $\mathrm{X}$ activating mixture. This was carried out essentially as described in the general scheme above, but with factor $\mathrm{Xa}(1 \mathrm{nM})$ added $10 \mathrm{~s}$

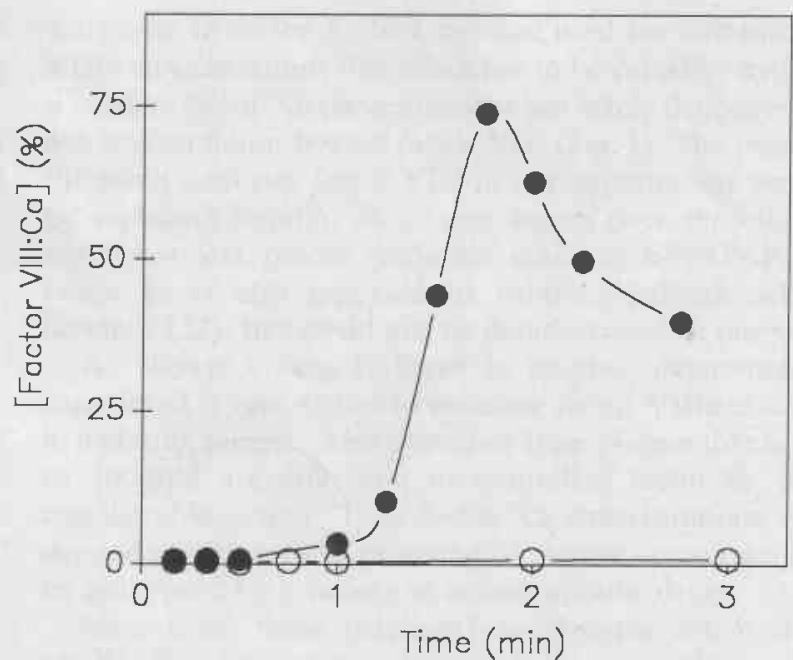

Fig. 4 Specificity of the factor VIIIa assay in thromboplastin activated plasma. $10 \mu \mathrm{l}$ of a 1 in 18 dilution of thromboplastin in a $167 \mathrm{mM} \mathrm{CaCl}_{2}$ solution were added to $90 \mu \mathrm{l}$ of defibrinated plasma (final dilution of 1 in 180). At various times, a sample of this mixture was diluted 1 in 90 in a cuvette containing factor IXa $(100 \mathrm{nM})$ (closed circles) or no factor IXa (open circles), PL $(20 \mu \mathrm{M}), \mathrm{Ca}^{2+}(5 \mathrm{mM})$ and $\alpha$-NAPAP $(1 \mu \mathrm{M})$ in buffer, so as to obtain a final dilution of the plasma of 1 in 100 . After $10 \mathrm{~s}$, factor Xa chromogenic substrate was added, to a concentration of $400 \mu \mathrm{M}$. After another $10 \mathrm{~s}$, factor $\mathrm{X}(0.33 \mu \mathrm{M})$ was added to initiate the activation reaction, and absorbance was measured during 2 min. Factor VIIIa concentrations are plotted as a percentage of the total factor VIII level

after the addition of factor $\mathrm{X}$. The experiment, performed with pooled normal plasma, hemophilia A plasma, euglobulin solution or buffer, resulted in absorbance-time curves that were nearly identical (less than $3 \%$ deviation at $5 \mathrm{~min}$ ). This indicates that all reactions of factor $\mathrm{Xa}$, except for the amidolysis of the chromogenic substrate, were indeed effectively inhibited.

\section{Standard Curve}

For the concentrations used, i.e. factor IXa $100 \mathrm{nM}$, PL $20 \mu \mathrm{M}$ and factor VIIIa less than $50 \mathrm{pM}$, the amount of complete tenase that is formed is expected to depend only on the concentration of factor VIIIa, since published apparent $K_{\mathrm{d}}$ values for factor IXa on a mixture of phospholipid and factor VIIIa are below $10 \mathrm{nM}(21,27)$. Our strategy to establish this was first to find a way to stabilize factor VIIIa, so that all factor VIII in a plasma sample could be activated without inactivation going on simultaneously. Then the concentration of factor VIIIa could be varied simply by varying the factor VIII concentration by way of mixing normal plasma with hemophilia A plasma, and adding thrombin to this mixture.

Purified factor VIIIa has been found to be stabilized by complex formation with factor IXa on a negatively charged phospholipid surface in the presence of $\mathrm{Ca}^{2+}$ (32). It turned out that stability of VIIIa was achieved for about $20 \mathrm{~s}$ when plasma was diluted first in a mixture of factor $\mathrm{IXa}, \mathrm{PL}$, and $\mathrm{Ca}^{2+}$, and then activated with a large amount of thrombin (100 nM) (Fig. 2).

Fig. 2 also shows that the level of the quadratic coefficient did not increase when the double amount $(200 \mathrm{nM})$ of thrombin was used, indicating that all the factor VIII had indeed been activated.

Plasma samples with different factor VIII concentrations were obtained by mixing pooled normal plasma and hemophilia A plasma in various ratios. The factor VIII in these samples was 
completely activated as described above. The chromogenic substrate for factor Xa and $\alpha$-NAPAP were added at $45 \mathrm{~s}$, that is $15 \mathrm{~s}$ after thrombin addition.

Fig. 3 shows that $f([$ VIIIa]) is linearly proportional to VIIIa concentrations ranging from 0 to $100 \%$ of factor VIIIa in pooled normal plasma. This reduces equation (I) to

$f([$ VIIIa $])=k_{1} \cdot[$ VIIIa $]$

so that equation (III) becomes:

$A(t)=A_{0}+k_{2} \cdot[\mathrm{Xa}]_{0} \cdot t+1 / 2 \cdot k_{1} \cdot k_{2} \cdot[\mathrm{VIIIa}] \cdot t^{2}$

The value of $1 / 2 \cdot k_{1} \cdot k_{2}$ was found to be $1.164 \pm 0.011$ (S.E.) $\mathrm{mA}$ $\min ^{-2} \%$ VIIIa $^{-1}$. Assuming $100 \%$ VIII to be $1 \mathrm{nM}(33,34)$, and using a value of $170 \mathrm{~mA} / \mathrm{nM}$ for $k_{2}$ (as previously mentioned), $k_{1}$ is estimated to be $137 \mathrm{~min}^{-1} \cdot(\mathrm{nM} \mathrm{Xa/nM} \mathrm{VIIIa).}$

\section{Specificity of the Assay}

Aspecificity of the factor VIIIa assay can be introduced at two levels: conversion of chromogenic substrate by anything other than factor Xa generated in the assay mixture, and activation of factor $\mathrm{X}$ in the assay mixture by anything other than the IXaVIIIa complex. The first means of aspecificity happens not to have an influence on the assay at all, since it only affects the linear coefficient of the quadratic equation describing the absorbance time curves (eq. V), whereas the factor VIIIa concentration only appears in the quadratic coefficient.

A small amount of aspecific activation of factor $X$ is of course expected to be caused by factor IXa which is not complexed to factor VIIIa. Since the assay is intended to measure factor VIIIa concentrations in a plasmatic environment, aspecific activation of factor $\mathrm{X}$ in the assay mixture may also come from the extrinsic factor $\mathrm{X}$ activator, the complex of tissue factor with factor VIIa.

The specificity of the factor VIIIa assay scheme was tested using buffer, non-activated plasma and thromboplastin (final dilution 1 in 180) activated plasma. This dilution of thromboplastin clotted uninhibited, non-defibrinated plasma in $70 \mathrm{~s}$. When we employed the general scheme described above to measure factor VIIIa activity in buffer and non-activated plasma, identical control values for the quadratic coefficient of $0.6 \mathrm{~mA} / \mathrm{min}^{2}$ were found. Als already mentioned, this value is the result of the slow activation of factor $\mathrm{X}$ by IXa in the presence of phospholipid and $\mathrm{Ca}^{2+}$, but without factor VIIIa.

In order to be able to determine any aspecificity in thromboplastin activated plasma, we suppressed the factor VIIIa based acceleration of factor $X$ activation. This was done by excluding factor IXa from the factor $X$ activating mixture, so that any factor $X$ activation would be caused by constituents from the thromboplastin activated plasma. Fig. 4 shows that very little factor $\mathrm{X}$ activating activity could be detected. The absorbance values obtained in the absence of factor IXa were so low, that a quadratic curve could not reliably be fitted to the experimental absorbance-time data. Instead, we made an estimation of the maximal values of the quadratic coefficient by assuming the constant and linear coefficient to be zero, and calculating the quadratic coefficient from $1 / 2 \cdot k_{1} \cdot k_{2} \cdot$ [VIIIa] $=A(t) / t^{2}$ at $t=$ 2 min.

\section{Discussion}

Although thrombin seems to be the only physiological activator (4), factor $\mathrm{Xa}$ was shown to be able to activate factor VIII in purified systems (18-21). Factor X activated in a system containing factor IXa, factor VIII, phospholipid and $\mathrm{Ca}^{2+}$ causes generation of factor VIIIa that in turn will accclerate the activation of factor $\mathrm{X}$. In a method used for determining factor VIII concentrations this effect has to be carefully avoided, since it renders factor Xa concentrations not solely dependent on VIIIa but also on non-activated factor VIII (Fig. 1). The possibility that thrombin activates factor VIII in our experiments was excluded by replacing hirudin, in a large excess over thrombin, for the somewhat less potent thrombin inhibitor $\alpha$-NAPAP. Although factor $\mathrm{Xa}$ is also reported to exhibit feedback activation of factor X (22), this could not be demonstrated in our system.

As shown in Fig. 1, there is another phenomenon to be considered if one wishes to measure factor VIIIa concentrations in a plasma sample. Anti-proteases from plasma that is diluted up to 100 -fold are still able to neutralize factor $\mathrm{Xa}$ to a quite considerable extent. Thus factor Xa concentrations would also depend on the anti-Xa potential of plasma, a parameter that can be influenced by a variety of antithrombotic drugs.

Since these "side reactions" involve the active site of factor Xa, the obvious way to suppress them would be an inhibition of this active site. The conversion of chromogenic substrate should not be affected, however. It is shown in Fig. 2 that this could be accomplished by a high concentration of chromogenic substrate for factor Xa. Factor Xa, then, is inhibited and measured in the same time.

Now, the course of absorbance in time is the result of two simultaneous reactions, the activation of factor $X$, and the amidolysis by factor $\mathrm{Xa}$ of chromogenic substrate. The latter reaction can initially be considered to be of first order, until an absorbance value of about 0.400 O.D. units.

In case of linearity between amidolysis and factor Xa concentration, the first derivative of the absorbance-time curve, $\mathrm{d} A / \mathrm{d} t$, is a function only of the other reaction going on in the mixture, viz. factor $X$ activation in time by the tenase complex (eq. I). In all experiments performed, with activated factor VIII ranging from 0 to $100 \%$, factor $\mathrm{X}$ activation was linear in time for at least $1 \mathrm{~min}$. Care was taken to use only that part of the absorbance-time curve for parameter estimation (eqs. III and V).

Lollar et al. have shown that purified porcine factor VIIIa is markedly stabilized by factor IXa, PC:PS vesicles, and $\mathrm{Ca}^{2+}$, which prolong the half-life time from $7 \mathrm{~min}$ to about $1 \mathrm{~h} \mathrm{(32).} \mathrm{As}$ thrombin-activated factor VIII in plasma is much more unstable than its purified counterpart, so is factor VIIIa in plasma that is diluted 1 in 100 in a mixture containing factor IXa, phospholipid and $\mathrm{Ca}^{2+}$. It is stable for about $25 \mathrm{~s}$, but this is followed by a rapid decrease, with a $50 \%$ reduction in no more than $3 \mathrm{~min}$. The question about the cause of this difference in stability of native compared to purified VIIIa remains unanswered. It seems unlikely that protein $\mathrm{C}$ is activated in our system, as thrombomodulin is not present in plasma. Furthermore, it is reported that loss of cofactor activity of factor VIIIa does not have to be concomitant with a major alteration of its primary structure (32). Perhaps the recently published $\mathrm{pH}$ dependence of the stability of porcine factor VIIIa provides an explanation (31).

The short-lived stability of factor VIIIa proved sufficient to allow complete activation of all factor VIII, and thus enabled us to reliably vary the factor VIIIa concentration in order to determine just how factor $\mathrm{X}$ activation is a function of factor VIIIa concentration. The observed linearity is in agreement with published apparent $K_{\mathrm{d}}$ values for the tenase complex, which are lower than $10 \mathrm{nM}(21,27)$, so that factor IXa in a concentration of $100 \mathrm{nM}$ is predicted to saturate factor VIIIa in concentrations that prevail in our system $(0-50 \mathrm{pM})$. Wagenvoord $(23)$ showed that factor IXa at concentrations higher than $50 \mathrm{nM}$ binds factor VIIIa optimally in a similar system.

The method we arrived at does in fact not measure factor VIIIa concentrations per se, but rather factor $\mathrm{X}$ activating activity. By choosing the proper conditions, it was made specific for factor- 
VIIIa. All unwanted side-reactions involving factor Xa could be inhibited. Any substance present in the sample diluted in the assay mixture, that has the capability to split the Xa chromogenic substrate (e.g. Xa that would be present in plasma) will only change the linear coefficient in the quadratic equation describing the course of absorbance in time, and will therefore not influence the estimation of the factor VIIIa concentration. Factor IXa in the presence of PS: $\mathrm{PC}$ vesicles and $\mathrm{Ca}^{2+}$ ions, slowly activates factor X. As the concentration of IXa is fixed at $100 \mathrm{nM}$ this will always produce the same small (control) value of the quadratic coefficient. Furthermore, factor $\mathrm{X}$ activation by everything but factor VIIIa from thromboplastin activated plasma, notably the extrinsic factor $\mathrm{X}$ activator, the complex of factor VIIa with tissue factor, appeared to be negligible (Fig. 4).

A number of reports have appeared describing assay systems of activated factor VIII in purified systems $(17,19,20,21)$. In all of those systems care should, and in general, has been taken to avoid activation of factor VIII by factor Xa. This can be done by careful selection of the concentration of the reactants and by limiting the time the reaction is allowed to proceed. However, when attempting to measure factor VIII activation in plasma an additional problem springs to life i.e. factor $\mathrm{Xa}$ inactivation by protease inhibitors. This is a phenomenon that cannot be dealt with by adaptation of concentrations and reaction times. It is all the more dangerous because it will not affect the calibration curve, where the large quantity of thrombin added to the diluted plasma in order to activate all factor VIII present in that sample will also titrate all available antiproteases, so that factor $\mathrm{Xa}$ inactivation is precluded. As shown, the present method effectively deals with both side reactions in a relatively simple way.

Because the factor VIIIa assay is specific, sensitive and has a well defined theoretical base, it should make possible a thorough investigation of the physiology of factor VIII activation and inactivation, and its role in the overall process of coagulation in a close to physiological environment.

\section{REFERENCES}

1. Hurlet-Birk Jensen A, Béguin S, Josso F. Factor V and VIII activation "in vivo" during bleeding. Evidence of thrombin formation at the early stage of hemostasis. Pathol Biol 1976; 24: 6-10.

2. Colman RW. The effect of proteolytic enzymes on bovine factor V. Kinetics of activation and inactivation by bovine thrombin. Biochemistry 1969; 4: 1438-44.

3. Lindhout MJ, Jackson CM. Activation of bovine factor $V$ by thrombin and a protease from Russell's viper venom (RVV). Thromb Haemostas 1979; 42: 491 (Abstr).

4. Pieters J, Hemker HC, Lindhout T. In Situ Generated Thrombin is the only enzyme that effectively activates factor VIII and factor V in plasma. Blood 1989; 74: 1021-4.

5. Rapaport SI, Hjort PF, Patch MJ. Further evidence that thrombin activation of factor VIII is an essential step in intrinsic clotting. Scand J Clin Lab Invest Suppl 1965; 17: 84-8.

6. Biggs R, Macfarlane RG, Denson WE, Ash BJ. Thrombin and the interaction of factors VIII and IX. Br J Haematol 1965; 11: 276-95.

7. Hemker HC, Kahn MJP. Reaction sequence of blood coagulation. Nature 1967; 215: 1201.

8. Osterud B, Rapaport SI, Schiffman S, Chong MMY. Formation of intrinsic factor $\mathrm{X}$ activator with special reference to the role of thrombin. Br J Haematol 1971; 21: 643-60.

9. Hultin MB, Nemerson Y. Activation of factor X by factors IXa and VIII; a specific assay for factor IXa in the presence of thrombinactivated factor VIII. Blood 1978; 52: 928-40.

10. Davey MG, Luscher EF. Actions of thrombin and other proteolytic enzymes on blood platelets. Nature $1967 ; 216$ : 857-8.
11. Bevers EM, Comfurius P, van Rijn JLML, Hemker HC, Zwaal RFA. Generation of prothrombin converting activity and the exposure of phosphatidylserine at the outer surface of platelets. Eur J Biochem 1982; 122: 429-36.

12. Soulier P, Larrieu MJ. Déficit en 3ème facteur prothromboplastique plasmatique. Rapports entre le PTA et le facteur Hageman. Thromb Diathes Haemorrh 1958; 2: 1-23.

13. Rapaport SI, Schiffman S, Patch MJ, Ware AG. A simple, specific one-stage assay for plasma thromboplastin antecedent activity. J Lab Clin Med 1961; 57: 771-80.

14. Hardisty RM, Macpherson JC. A one-stage factor VIII (antihemophilic globulin) assay and its use on venous and capillary plasma. Thromb Diathes Haemorrh 1962; 7: 215-29.

15. Veltkamp JJ, Drion EF, Loeliger EA. Detection of the carrier state in hereditary coagulation disorders-I, II. Thromb Diathes Haemorrh 1968; 19: 279-303 and 403-22.

16. Suomela $H$, Blombäck $B$. The activation of factor $X$ evaluated by using synthetic substrates. Thromb Res 1977; 1: 267-81.

17. Van Dieijen G, Tans G, Rosing J, Hemker HC. The role of phospholipid and factor VIIIa in the activation of bovine factor $\mathrm{X}$. J Biol Chem 1981; 256: 3433-42.

18. Vehat GA, Davie EW. Preparation and properties of bovine factor VIII (antihemophilic factor). Biochemistry 1980; 19: 401-10.

19. Hultin MB. Role of human factor VIII in factor X activation. J Clin Invest 1982; 69: 950-5.

20. Lollar P, Knutson GJ, Fass DN. Activation of porcine factor VIII by thrombin and factor Xa. Biochemistry 1985; 24: 8056-64.

21. Neuenschwander P, Jesty J. A comparison of phospholipid and platelets in the activation of human factor VIII by thrombin and factor Xa, and in the activation of factor X. Blood 1988; 72: 1761-70.

22. Jesty J, Spencer AK, Nemerson Y. The mechanism of activation of factor X. J Biol Chem 1974; 249: 5614-22.

23. Wagenvoord R, Hendrix H, Hemker HC. Development of a simple chromogenic factor VIII-assay for clinical use. Hacmostasis 1989; 19: 196-204.

24. Fujikawa $K$, Legaz ME, Davie EW. Bovine factor $X_{1}$ and $X_{2}$ (Stuart factor). Isolation and characterization. Biochemistry $1972 ; 11$ :

25. Fujikawa K, Legaz ME, Davie EW. Bovine factor $X_{1}$ (Stuart factor). Mechanism of activation by a protein from Russel's viper venom. Biochemistry 1972; 11: 4892-9.

26. Wagenvoord R, Hendrix H, Soria C, Hemker HC. Localization of the inhibitory site(s) of pentosan polysulphate in blood coagulation. Thromb Haemostas 1988; 60: 220-5.

27. Van Dieijen G, Van Rijn J, Govers-Riemslag J, Hemker HC, Rosing J. Assembly of the intrinsic factor $\mathrm{X}$ activating complex - Interactions between factor IXa, factor VIIIa and phospholipid. Thromb Haemostas 1985; 53 (3): 396-400.

28. Rosing J, Tans G, Govers-Riemslag JWP, Zwaal RFA, Hemker HC. The role of phospholipids and factor $\mathrm{V}_{\mathrm{a}}$ in the prothrombinase complex. J Biol Chem 1980; 255: 274-83.

29. Hemker HC, Willems GM, Béguin S. A computer assisted method to obtain the prothrombin activation velocity in whole plasma independent of thrombin decay processes. Thromb Haemostas 1986; 56: 9-17.

30. Owren PA, Aas K. The control of dicumarol therapy and the quantitative determination of prothrombin and proconvertin. Scand $\mathrm{J}$ Clin Lab Invest 1951; 3: 201-18.

31. Lollar P, Parker CG. pH-dependent denaturation of thrombinactivated porcine factor VIII. J Biol Chem 1990; 265: 1688-92.

32. Lollar P, Knutson GJ, Fass DN. Stabilization of thrombin-activated porcine factor VIII by factor IXa and phospholipid. Blood 1984; 63:
1303-8.

33. Kane WH, Davie EW. Blood coagulation factors V and VIII: structural and functional similarities and their relationship to hemorrhagic and thrombotic disorders. Blood 1988; 71: 539-55.

34. Hoyer LW. The factor VIII complex. Structure and function. Blood 1981; 58: 1-13.

Received August 8, 1990 Accepted after revision March 21, 1991 